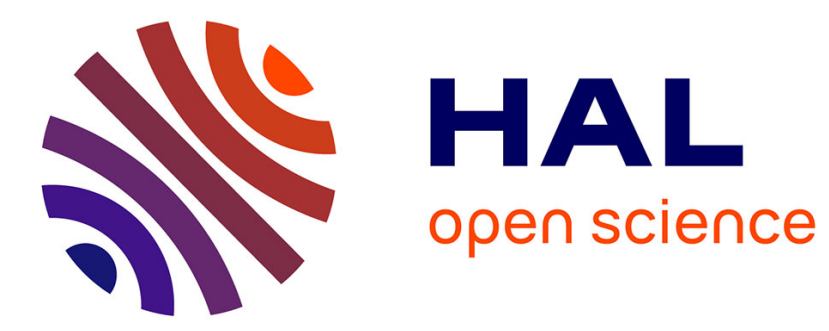

\title{
Preparation of ( $\mathrm{Zn}, \mathrm{Fe}) \mathrm{Fe} 2 \mathrm{O} 4$ Thin Film by MOCVD
}

S. Ito, T. Mochizuki, M. Chiba, K. Akashi, N. Yoneda

\section{To cite this version:}

S. Ito, T. Mochizuki, M. Chiba, K. Akashi, N. Yoneda. Preparation of (Zn, Fe)Fe2O4 Thin Film by MOCVD. Journal de Physique IV Proceedings, 1997, 07 (C1), pp.C1-491-C1-492. 10.1051/jp4:19971200 . jpa-00254851

\section{HAL Id: jpa-00254851 https://hal.science/jpa-00254851}

Submitted on 1 Jan 1997

HAL is a multi-disciplinary open access archive for the deposit and dissemination of scientific research documents, whether they are published or not. The documents may come from teaching and research institutions in France or abroad, or from public or private research centers.
L'archive ouverte pluridisciplinaire HAL, est destinée au dépôt et à la diffusion de documents scientifiques de niveau recherche, publiés ou non, émanant des établissements d'enseignement et de recherche français ou étrangers, des laboratoires publics ou privés. 


\title{
Preparation of $(\mathrm{Zn}, \mathrm{Fe}) \mathrm{Fe}_{2} \mathrm{O}_{4}$ Thin Film by MOCVD
}

\author{
S. Ito, T. Mochizuki, M. Chiba, K. Akashi and N. Yoneda*
}

Department of Industrial Chemistry, Faculty of Science and Technology, Science University of Tokyo, Noda Chiba 278, Japan

* Faculty of Humanities, Seitoku University, Matsudo Chiba 271, Japan

\begin{abstract}
Zn}, \mathrm{Fe}) \mathrm{Fe}_{2} \mathrm{O}_{4}$ thin films have been prepared by MOCVD, applying a novel evaporation method for $\mathrm{MO}$ reagents;

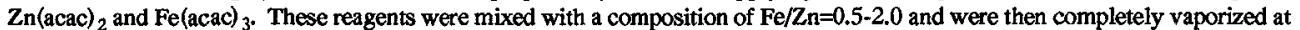
$215^{\circ} \mathrm{C}$. By the use of single evaporation vessel, the arrangement of MOCVD apparatus has been simple. The vapors with a constant ratio were evolved from the vessel to deposition zone to react with oxygen at $500^{\circ} \mathrm{C}$ for $30 \mathrm{~min}$. The reproducibility was established on the relationship between mixing ratio and film composition. In addition, high crystallinity was obtained even at $500^{\circ} \mathrm{C}$ without annealing at higher temperature. The magnetic properties of the $\mathrm{Zn}{ }_{0.73} \mathrm{Fe}_{0.27} \mathrm{Fe}_{2} \mathrm{O}_{4}$ thin film were measured as 38 emu/g and $110 \mathrm{Oe}$ at $25^{\circ} \mathrm{C}$.
\end{abstract}

\section{INTRODUCTION}

In MOCVD using powder reagents, the composition control of the deposited film of complex oxide such as ferrite is generally difficult. This is because the evaporation rate of each MO reagent is not constant during the film deposition. On the other hand, the vapor composition would be constant, if mixed $\mathrm{MO}$ reagents were completely vaporized in a vessel. In addition, the amount of the reagents required to make a thin film is not so much. In this study, the vapors were supplied from a vessel containing a constant composition of the $\mathrm{MO}$ vapors. This novel method has been applied to the film growth of $(\mathrm{Zn}, \mathrm{Fe}) \mathrm{Fe}_{2} \mathrm{O}_{4}$, in which reproducibility of the composition and magnetic properties of the film were investigated.

\section{EXPERIMENTAL}

Figure 1 shows schematic diagram of the apparatus. The apparatus became simple compared with the conventional one, because of single evaporation vessel without carrier gas. Two kinds of acetylacetonate complexes, $\mathrm{Zn}$ (acac) ${ }_{2}$ and $\mathrm{Fe}(\mathrm{acac})_{3}$ were selected as MO reagents. These reagents (total amount : ca. $0.2 \mathrm{~g}$ ) were mixed with a composition of $\mathrm{Fe} / \mathrm{Zn}=0.5-2.0$ and charged into the evaporation vessel. After evacuating the system under 5 Torr, leak valve was closed and the vessel was heated at $215^{\circ} \mathrm{C}$ to vaporize the mixed reagents completely. The leak valve was then opened to evolve the vapor with a constant composition. The vapors were transported to the deposition zone to react with oxygen $(0-200 \mathrm{ml} / \mathrm{min})$ and deposited on a borosilicate glass $(9 \times 9 \times 0.2 \mathrm{~mm})$ at $500^{\circ} \mathrm{C}$ for $30 \mathrm{~min}$. The deposited films were characterized by $X$-ray diffraction (XRD) and scanning electron microscope (SEM). The film composition was determined by inductively coupled plasma emission spectrometry. The magnetic properties of the film were measured by vibrating sample magnetometer.

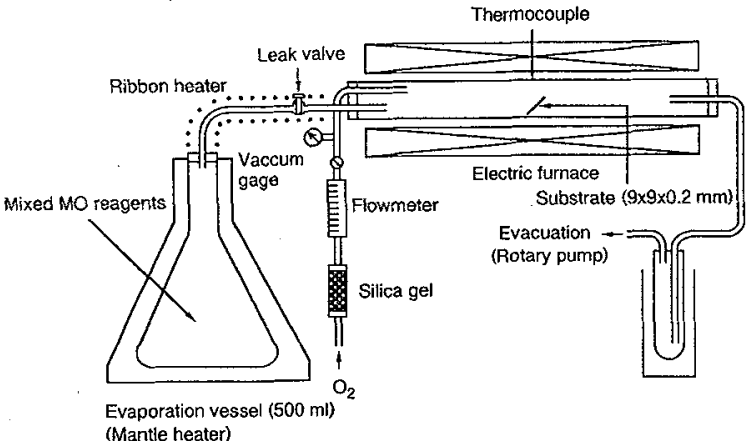

Figure 1 : MOCVD apparatus for $(\mathrm{Zn}, \mathrm{Fe}) \mathrm{Fe}_{2} \mathrm{O}_{4}$ thin films. 


\section{RESULTS AND DISCUSSION}

\subsection{Determination of evaporation temperature}

$\mathrm{Fe}(\mathrm{acac})_{3}(0.2 \mathrm{~g})$ powder was completely vaporized by heating an evaporation vessel at $210^{\circ} \mathrm{C} . \alpha-\mathrm{Fe}_{2} \mathrm{O}_{3}$ film was obtained by the reaction of the vapor and oxygen $(100 \mathrm{ml} / \mathrm{min})$. When $\mathrm{Zn}(\mathrm{acac})_{2}$ powder $(0.2 \mathrm{~g})$ was heated in the the vessel at $140^{\circ} \mathrm{C}$, the powder was disappeared. $\mathrm{ZnO}$ thin film oriented (100) was obtained by the reaction of the vapor and oxygen ( 100 $\mathrm{m} 1 / \mathrm{min}$ ). Therefore, the evaporation temperature of the mixed reagents was determined as $215^{\circ} \mathrm{C}$.

\subsection{Determination of oxygen flow rate}

Figure 2 shows $\mathrm{X}$-ray diffraction pattern of the film obtained at $500^{\circ} \mathrm{C}$ under the oxygen flow rate of $150 \mathrm{ml} / \mathrm{min}$. The pattern was clearly identified as that of spinel phase. The film thickness was estimated to be ca. $1 \mu \mathrm{m}$, which was calculated from the amount of deposit determined by chemical analysis. It was the maximum under this oxygen flow rate. Using a conventional apparatus, $\mathrm{Mn}-\mathrm{Zn}$ ferrite and $\mathrm{Ni}-\mathrm{Zn}$ ferrite thin films obtained at $500^{\circ} \mathrm{C}$ required to be annealed at higher temperature to obtain the crystallinity and high magnetization $[1,2]$. In our apparatus, the vapors would be supplied with a constant ratio during the film growth. Therefore, the film with high crystallinity may be obtained even at $500^{\circ} \mathrm{C}$.

\subsection{Reproducibility of the film composition and the magnetic properties}

Under the suitable conditions described above, the films were deposited at different mixing ratios of $\mathrm{MO}$ reagents. The compositions obtained were $1.05,2.47$ and 3.35 , against $0.5,1.0$ and 2.0 of the mixing ratios, respectively. The films contained excess amount of Fe. The vapor species of $\mathrm{Zn}\left(\mathrm{acac}_{2}\right.$ may be decomposed at lower temperature region of the furnace. Figure 3 shows the relationship between film composition and mixing ratio of $\mathrm{MO}$ reagents; $\mathrm{Fe} / \mathrm{Zn}=\mathbf{0 . 8 - 1 . 1}$. The film composition was controlled by selecting the mixing ratio of the reagents. At $\mathrm{Fe} /$ $\mathrm{Zn}=0.9$, the stoichiometric $\mathrm{ZnFe}_{2} \mathrm{O}_{4}$ film was obtained. According to SEM observation, the film consisted of fine grains with ca. 0.1 $\mu \mathrm{m}$. Table 1 shows saturation magnetization and coercive force of the films. Although stoichiometric $\mathrm{ZnFe}_{2} \mathrm{O}_{4}$ is not ferromagnetic material, $(\mathrm{Zn}, \mathrm{Fe}) \mathrm{Fe}_{2} \mathrm{O}_{4}$ would reveal the magnetization due to $\mathrm{Fe}^{2+}$. Table 1 also gives $\sigma_{0}$ values calculated from the data in Ref. 3 . The large difference from $\sigma_{\mathrm{S}}$ and $\sigma_{0}$ indicates that ion distribution in the deposit may be different from that in equilibrium state. It is concluded that the novel evaporation method contributes the reproducibility and the crystallinity of the film obtained by MOCVD.

\section{References}

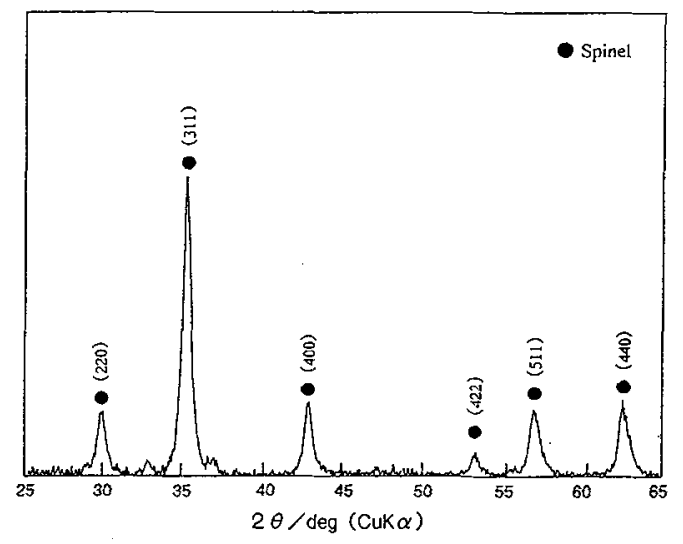

Figure 2 : XRD pattern of thin film deposited on a borosilicate glass substrate.

Mixing ratio of $\mathrm{MO}$ reagents:Fe/ $\mathrm{Zn}=2.0$, Flow rate of $\mathrm{O}_{2}: 150$ $\mathrm{ml} / \mathrm{min}$, Deposition temperature:500 ${ }^{\circ} \mathrm{C}$, Deposition time: $30 \mathrm{~min}$.

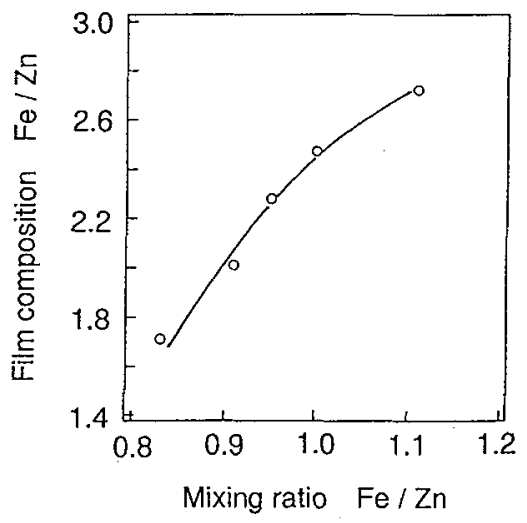

Figure 3 : Relationship between film composition and mixing ratio of MO reagents.

Flow rate of $\mathrm{O}_{2}: 150 \mathrm{ml} / \mathrm{min}$, Deposition temperature: $500^{\circ} \mathrm{C}$, Deposition time: $30 \mathrm{~min}$.

Table 1 : Saturation magnetization $\left(\sigma_{s}\right)$ and coercive force (Hc) of the films (at $25^{\circ} \mathrm{C}$ ).

\begin{tabular}{cccc}
\hline Film & $\sigma_{\text {s }}(\mathrm{emu} / \mathrm{g})$ & $\sigma_{0}(\mathrm{emu} / \mathrm{g})^{3)}$ & $\mathrm{Hc}(\mathrm{Oe})$ \\
\hline $\mathrm{Zn}_{0.86} \mathrm{Fe}_{0.14} \mathrm{Fe}_{2} \mathrm{O}_{4}$ & 19 & - & 116 \\
$\mathrm{Zn}_{0.83} \mathrm{Fe}_{0.17} \mathrm{Fe}_{2} \mathrm{O}_{4}$ & 18 & - & 84 \\
$\mathrm{Zn}_{0.73} \mathrm{Fe}_{0.27} \mathrm{Fe}_{2} \mathrm{O}_{4}$ & 38 & 126 & 110 \\
$\mathrm{Zn}_{0.54} \mathrm{Fe}_{0.46} \mathrm{Fe}_{2} \mathrm{O}_{4}$ & 16 & 131 & 50 \\
$\mathrm{Zn}_{0.14} \mathrm{Fe}_{0.86} \mathrm{Fe}_{2} \mathrm{O}_{4}$ & 30 & 117 & 98 \\
\hline
\end{tabular}

Flow rate of $\mathrm{O}_{2}: 150 \mathrm{ml} / \mathrm{min}$, Deposition temperature: $500^{\circ} \mathrm{C}$, Deposition time: $30 \mathrm{~min}$

[1] H. ITO, T. TAKEDA, and S. NAKA,J. Mater. Sci., 21 (1986) 3677.

[2] H. ITO, H. YAMAGUCHI, and S. NAKA,Yogyo-Kyoukai-Shi, 95 [1] (1987) 50.

[3] E. W. Gorter, Philips Res. Rep., 9 (1954) 295. 